\title{
Aplikasi Reservasi Tiket Bus pada Handphone Android menggunakan Web Service (Studi Kasus: PO. Rosalia Indah)
}

\author{
1) Fajar Fani Hartono, ${ }^{2}$ Hendry, ${ }^{3)}$ Ramos Somya \\ Fakultas Teknologi Informasi \\ Universitas Kristen Satya Wacana \\ Jl. Diponegoro 52-60, Salatiga 50711, Indonesia \\ Email: ${ }^{1)}$ fajar8091@ gmail.com, ${ }^{2}$ hendry@ staff.uksw.edu, \\ ramos.6005@gmail.com
}

\begin{abstract}
Presentation of ticket availability information is still a manual one problems faced by the travel services for passengers have come to the ticket agent to check availability.Therefore the need for a reservation system applications.Bus ticket reservation system used for passengers booking a trip without having to come to the agency. To facilitate passengers to access this system, the bus ticket reservation application built Androidbased mobile. Android is a collection of software intended for mobile devices includes an operating system. This application runs on the Android platform and integrate with applications residing on the server. Server is built to take advantage of web-based web service. Web Service provides a standardized communication among different software applications are different, and can run on various platforms and frameworks. Through the application of this reservation, the reservation transaction is expected to be done anywhere and anytime without being bound by time and place.
\end{abstract}

Keyword : Reservation, Android, web service

\section{Abstrak}

Penyajian informasi ketersediaan tiket yang masih manual menjadi salah satu permasalahan yang dialami oleh jasa travel karena calon penumpang harus datang ke agen untuk mengetahui ketersediaan tiket. Oleh karena itu perlu adanya suatu aplikasi sistem reservasi.Sistem Reservasi tiket bus digunakan calon penumpang untuk melakukan pemesanan tiket perjalanan tanpa harus datang ke agen. Untuk memudahkan calon penumpang dalam mengakses sistem in i, maka dibangun aplikasi reservasi tiket bus berbasis Android mobile. Android adalah ku mpulan perangkat lunak yang ditujukan bagi perangkat bergerak mencakup sistem operasi. Aplikasi ini berjalan pada platform Android dan berintegrasi dengan aplikasi yang berada di server. Server dibangun berbasis web yang memanfaatkan web service. Web Service menyediakan standar ko munikasi di antara berbagai aplikasi software yang berbeda-beda, dan dapat berjalan di berbagai platform maupun framework. Penelitian ini membahas tentang perancangan dan implementasi aplikasi sistem reservasi tiket bus berbasis Android mobile. Melalui aplikasi reservasi ini, diharapkan transaksi reservasi dapat dilakukan dimana saja dan kapan saja tanpa terikat dengan waktu dan tempat.

Kata Kunci : Reservasi, Android, web service

\section{Pendahuluan}

Perkembangan teknologi informasi yang sangat pesat memungkinkan terjadinya pemenuhan permintaan baik yang berupa informasi, jasa, atau barang secara lebih cepat dan cepat. Terlebih lagi perkembangan yang pesat di bidang mobile device, di mana kini perangkat mobile sudah di dukung oleh fitur internet. Kondisi ini yang akhirnya dimanfaatkan oleh perusahaan jasa travel untuk mengatasi permasalahan penyajian informasi khususnya dalam ketersediaan tiket dan proses reservasi yang masih manual. Keberadaan aplikasi reservasi pada perangkat mobile mampu mengatasi permasalahan yang terjadi di perusahaan jasa travel, karena dengan aplikasi tersebut konsumen dapat melakukan transaksi reservasi dimanapun dan kapan saja tanpa terikat dengan waktu.

Perkembangan teknologi tersebut yang akhirnya dimanfaatkan oleh perusahaan jasa travel PO. Rosalia Indah. PO. Rosalia Indah adalah sebuah perusahaan yang sedang berkembang pesat dan merupakan perusahaan pribumi yang diperhitungkan dalam percaturan bisnis jasa angkutan darat di Indonesia. Perusahaan yang selalu mengedepankan pelayanan, keamanan, kenyamanan serta kebersihan armadanya ini memiliki jalur trayek Jawa-Sumatra dengan dua sistem reservasi tiket yaitu sistem manual untuk pemesanan tiket yang dilakukan oleh konsumen melalui agen dan 
pemesanan via SMS (Short Message Service) oleh pelanggan. Namun keberadaan dua alternatif tersebut belum mampu memenuhi tingginya permintaan tiket yang berkisar 1959 tiket per hari.[1]. Berdasarkan angka permintaan tiket yang tinggi, penyajian informasi khususnya dalam ketersediaan tiket sering kali menjadi salah satu permasalahan karena konsumen harus datang ke agen untuk mengetahui ketersediaan tiket. Untuk itu perlu dibuat sistem reservasi yang dapat memberikan informasi yang lebih akurat dalam pemesanan tiket dan jadwal keberangkatan berbasis mobile. Melalui teknologi tersebut, user dapat melakukan transaksi reservasi tiket kapan saja dan dimana saja.

Perkembangan teknologi mobile yang sedang berkembang saat ini adalah Android. Android merupakan sistem operasi bergerak (mobile) yang menggunakan versi modifikasi dari kernel Linux. Sistem ini memiliki berbagai keunggulan sebagai software berbasis kode komputer yang bisa didistribusikan secara terbuka (open source), sehingga programmer bisa membuat aplikasi baru di dalamnya. Hal tersebut menjadikan android cocok untuk mendukung aplikasi reservasi berbasis mobile.

Berdasarkan permasalahan tersebut, maka dibutuhkan sebuah layanan yang mampu mendukung sebuah aplikasi client. Web service adalah layanan yang dirasa mampu mengatasi permasalahan tersebut. Web service yang berbasiskan XML sangat memungkinkan untuk diimplementasikan sehingga menjanjikan banyak kemudahan dan perbaikan dalam mendukung integrasi berbagai platform system dan aplikasi, baik melalui insfrastruktur Intranet maupun Internet/Eksternet[2].Keberadaan web service yang mampu mengelola administrasi dari penjualan tiket bus ini diharapkan dapat memudahkan agen dalam melakukan pekerjaannya, karena para agen cukup menyediakan device dan sebuah aplikasi client yang dapat mengolah transaksi yang dikirim oleh web service itu. Oleh karena itu muncullah keinginan untuk membangun sebuah aplikasi pemesanan tiket di PO. Rosalia Indah berbasis android mobile yang memanfaatkan web service guna memberikan pelayanan penyajian informasi yang lebih baik.

\section{Tinjauan Pustaka}

Penelitian sebelumnya adalah "perancangan aplikasi pemesanan tiket berbasis web" (study kasus: pemesanan tiket di PO. Maju Lancar) di mana dalam penelitian ini user dapat melakukan reservasi melalui sebuah aplikasi berbasis web. Aplikasi ini dibangun dengan menggunakan bahasa pemprogaman PHP dan MySql dan dirancang dengan berbasis web yang memberi fasilitas pemesanan tiket bus sesuai dengan jadwal keberangkatan, dan pemberian alternatif pemilihan bus la in apabila tiket bus yang diinginkan sudah habis[3].

Perkembangan teknologi smartphone Android dimanfaatkan dalam pengembangan di sektor kuliner. Di mana teknologi ini digunakan dalam pembuatan aplikasi delivery order di restoran. Aplikasi tersebut dibangun untuk memudahkan para kostumer dalam memesan makanan dan melihat promo makanan yang ada di dalam restoran. Sehingga cukup dengan sentuhan pada menu yang terdapat dalam aplikasi kostumer dapat memesan makanan yang diinginkan[4].

Pada penelitian ini akan dibahas mengenai pembuatan sistem reservasi tiket bus akan diterapkan pada Android mobile yang akan menampilkan jadwal keberangkatan bus, ketersediaan tiket bus dan tempat duduk, serta konfirmasi pembayaran tiket. Aplikasi yang akan dibangun ini merupakan aplikasi berbasis Android Mobile, dimana aplikasi ini akan memanfaatkan web service yang akan menyediakan method database. Dimana method-method tersebut akan memudahkan dalam mengakses database sehingga pengolahan data lebih cepat.

Android adalah kumpulan perangkat lunak yang ditujukan bagi perangkat bergerak mencakup sistem operasi, middleware, dan aplikasi kunci. Android merupakan sistem operasi yang dikembangkan dengan memanfaatkan linux kernel untuk smartphone yang dibuat oleh Google corporation. Platform pada Android terbuka bagi para pengembang untuk menciptakan aplikasi mereka sendiri untuk digunakan oleh bermacam peranti bergerak[5]. Arsitektur Android ditunjukkan pada Gambar 1. 


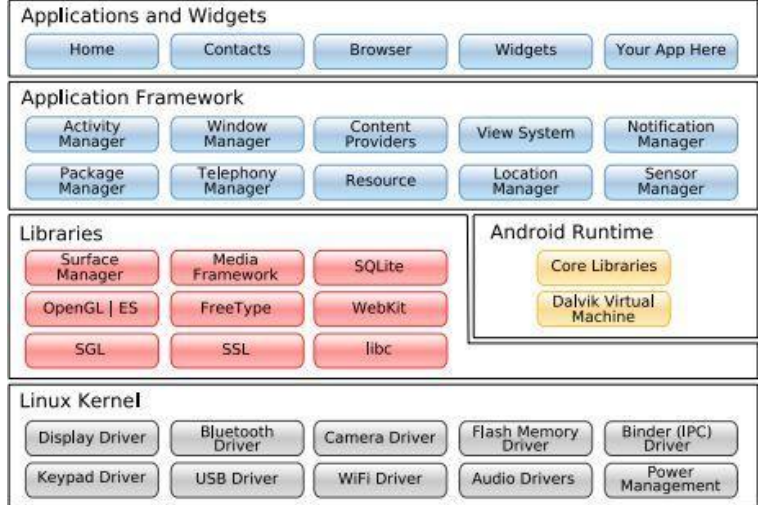

Gambar 1 Arsitektur Android[6]

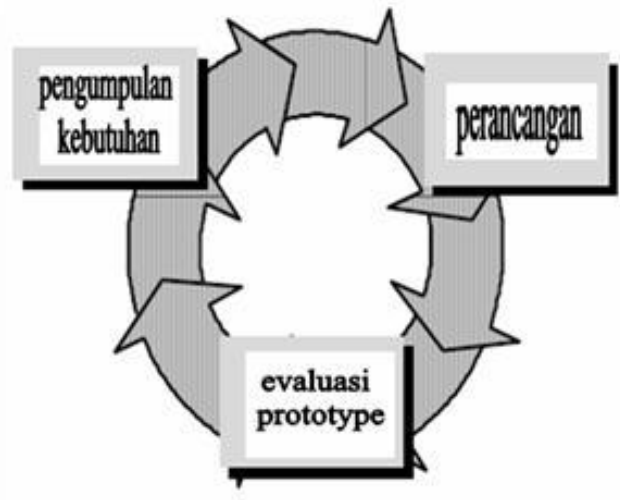

Gambar 2Metode Prototyping [9].

Arsitektur Android seperti yang ditunjukkan pada Gambar 1 terdiri dari 5 bagian utama, yaitu Application dan Widgets, Application Framework, Libraries, Android Runtime, dan Linux Kernel.

Web Service diartikan sebagai sebuah antar muka (interface) yang menggambarkan sekumpulan operasi-operasi yang dapat diakses dengan melalui jaringan, misalnya internet dalam bentuk pesan XML (eXtensible Markup Language)[7].Web Service menyediakan standar komunikasi di antara berbagai aplikasi software yang berbeda-beda, dan dapat berjalan di berbagai platform maupun framework. Web service dapat ditemukan, diakses, diuraikan berdasarkan pada XML dan protocol standart Web pada intranet, externet, dan internet. Karena web service menggunakan format data yang universal yaitu XML, maka web service juga mewariskan sifat multi-tier dari XML. Sehingga memungkinkan terjadi integrasi antara web service atau aplikasi[8].

\section{Metode Penelitian}

Perancangan sistem ini menggunakan metode prototyping. Prototyping adalah proses yang digunakan untuk membantu pengembangan perangkat lunak dalam membentuk model dari perangkat lunak yang harus dibuat. Metode ini dilakukan secara bertahap, yaitu dengan mengembangkan suatu prototype yang sederhana terlebih dahulu baru kemudian dikembangkan dari waktu ke waktu sampai perangkat lunak selesai dikembangkan.Prototype merupakan bentuk dasar atau model awal dari suatu sistem atau subsistem [9]. Gambar 2.

Secara garis besar terdapat tiga tahapan dalam metode prototyping ini, seperti terlihat pada

Metode prototyping seperti yang terlihat pada Gambar 2 terdiri dari tiga bagian utama yaitu:

- Pengumpulan kebutuhan

Tahap pertama yang dilakukan pada metode prototyping adalah pengumpulan kebutuhan.Pada tahap ini dilakukan dengan metode wawancara pada PO. Rosalia Indah. Dari wawancara yang telah dilakukan, dihasilkan data-data harga tiket, sebagai sample untuk aplikasi reservasi ini, akan memakai data harga tiket bulan Agustus.

\section{- Perancangan Sistem}

Langkah berikutnya dari metode ini adalah membuat rancangan sistem aplikasi, yaitu membangun sistem berdasarkan hasil dari tahap sebelumnya. Pada tahap ini perancangan sistem dilakukan dengan menggunakan UML (Unified Model Language) yang memanfaatkan tools rational rose, pada tahap ini pula dilakukan desain terhadap User Interface. Kemudian dilakukan perancangan tabel yang dibutuhkan dalam pembuatan aplikasi. Setelah semuanya selesai maka pada tahap ini aplikasi dibuat sampai selesai sesuai dengan user requirement yang diperoleh pada tahap awal.Arsitektur sistem dari sistem yang dibangun terlihat pada Gambar 3. 


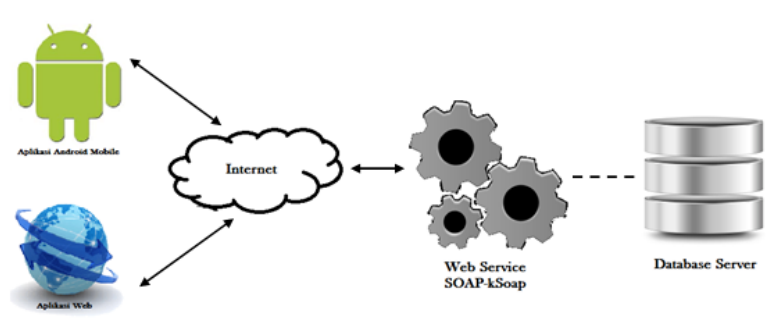

Gambar 3. Arsitektur Sistem

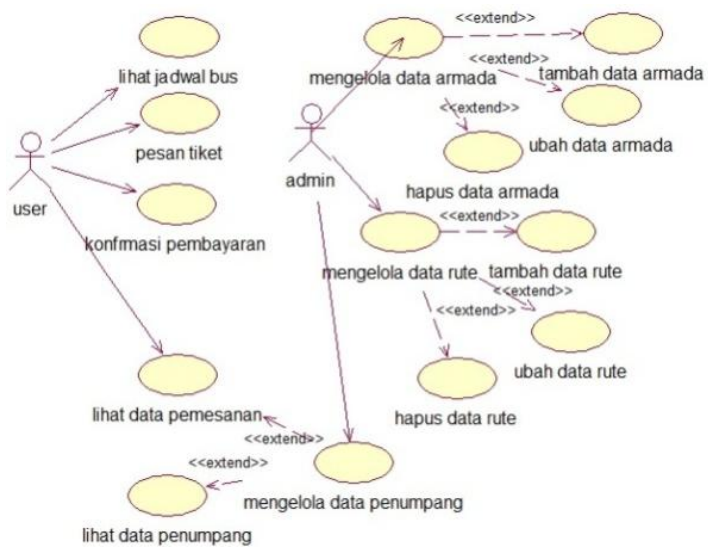

Gambar 4Use Case Diagram

Gambar 3 merupakan rancangan arsitektur aplikasi reservasi tiket bus. Aplikasi mobile diimplementasikan ke perangkat Android mobile. Aplikasi web diimplementasikan pada laptop/ PC. Semua perangkat harus terhubung dengan internet. Web service menghubungkan antara aplikasi mobile dan web.Library KSOAP digunakan untuk mengakses data pada database server.

Use CaseDiagram menggambarkan interaksi antara aktor-aktor dengan sistem yang dibangun[10], serta menggambarkan fungsionalitas yang dapat diberikan sistem kepada user. Dari dalam sistem yang akan dibangun terdapat dua aktor yang masing-masing memiliki hak akses yang berbeda-beda yaituuser, dan admin. User adalah masyarakat umum yang bisa mengakses sistem informasi dan memesan tiket bus di PO. Rosalia IndahAdmin adalah pegawai di PO. Rosalia Indah yang khusus menangani tiketting.

Gambar 4 menjelaskan interaksi antara aktor dalam sistem serta fungsionalitas yang diberikan kepada user,dan admin. Mengenai bagian-bagian yang tersedia untuk hak akses useryaitu dapat melakukan registrasi sebagai pelanggan sehingga dapat melakukan reservasi tiket kepada pihak PO. Rosalia Indah. Selain itu admindapat melakukan pengelolaan data armada yaitu menambah, edit dan delete ketersediaan armada, mengolah data rute bus yaitu tambah rute, edit rute, delete rute beserta jadwal keberangkatan, juga dapat mengolah data penumpang yaitu melihat data penumpang, mengubah data pesan tiket.

Activity diagram menggambarkan aliran aktifitas dalam sistem yang sedang dirancang, bagaimana masing-masing alir berawal, decision yang mungkin terjadi, dan bagaimana mereka berakhir[10].

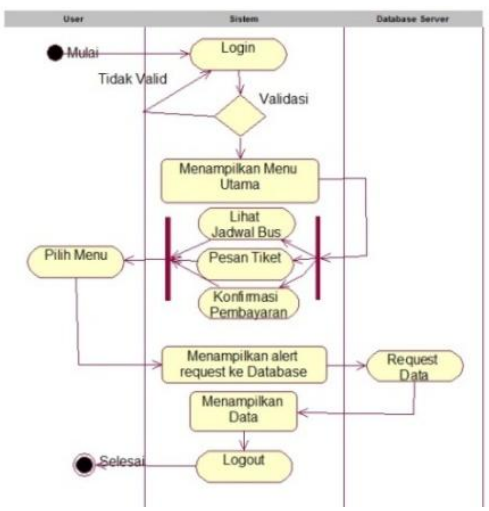

Gambar 5Activity Diagram user

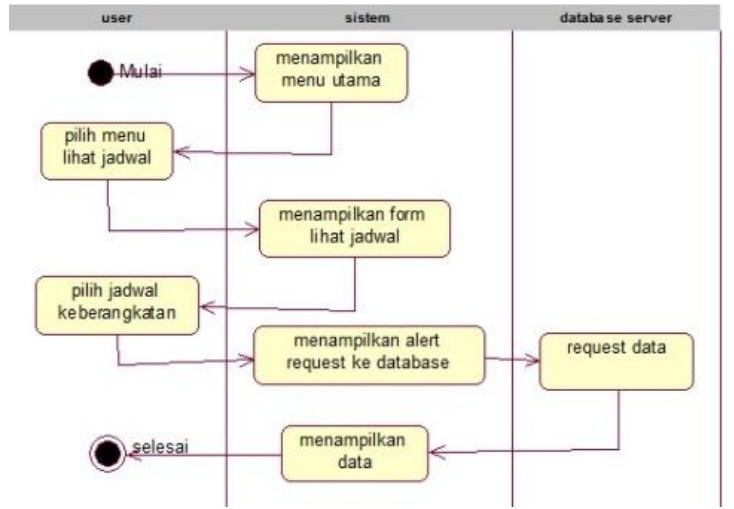

Gambar 6 Activity Diagram Lihat Jadwal 
Gambar5 menggambarkan aktifitas yang dapat dilakukan oleh user. Pertama yang dilakukan oleh user adalah melakukan login, jika berhasil maka user dapat masuk ke form utama. Pada form utama terdapat beberapa user, diantaranya lihat jadwal bus, pesan tiket dan konf irmasi pembayaran. Setelah user memilih salah satu menu secara otomatis sistem akan mengirimkan alert request ke database dan database akan menampilkan data. Setelah itu user dapat logout dari sistem.

Gambar 6 menggambarkan aktifitas yang dapat dilakukan oleh useruntuk melihat jadwal keberangkatan bus. Pertama yang dilakukan oleh user adalah memilih menu lihat jadwal, sistem akan menampilkanformlihat jadwal. Pada formlihat jadwal user harus memilih tanggal keberangkatan serta tujuan dari perjalanan. Setelah user memilih salah satu jadwal secara otomatis sistem akan mengirimkan alert request ke database dan database akan menampilkan data.

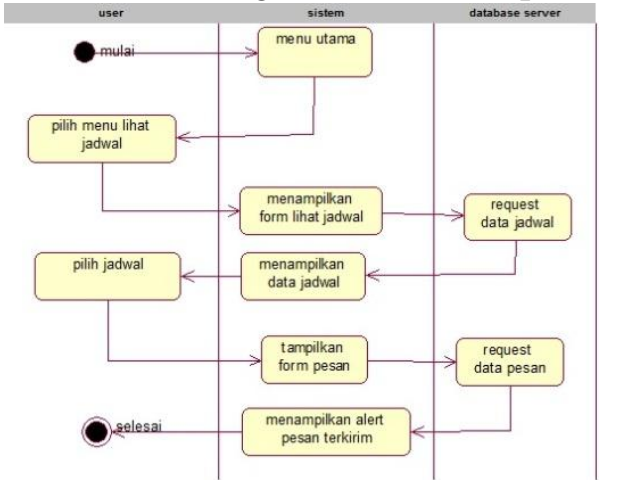

Gambar 7 Activity Diagram Pesan Tiket

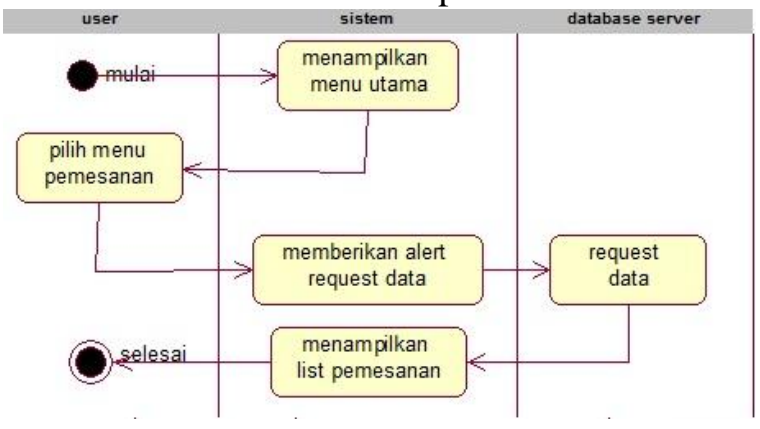

Gambar 8Activity Diagram Lihat Pemesanan

Gambar 7 menggambarkan aktifitas yang dapat dilakukan oleh useruntuk memesan tiket.Setelah sistem menampilkan data jadwal keberangkatan, user dapat memesan tiket sesuai jadwal keberangkatan.Setelah user memilih salah satu jadwal, agen keberangkatan, dan tempat duduk maka secara otomatis sistem akan mengirimkan request ke database dan sistem akan menampilkan alert bahwa pemesanan tiket telah berhasil.

Gambar 8 menggambarkan aktifitas lihat data pemesanan. Setelah user memesan tiket, user dapat melihat list data pemesanan tiket dengan memilih menu lihat pemesanan.

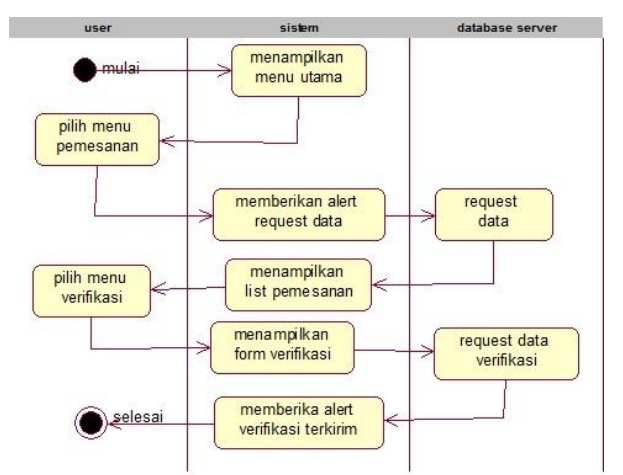

Gambar 9Activity Diagram verifikasi Pe mbayaran

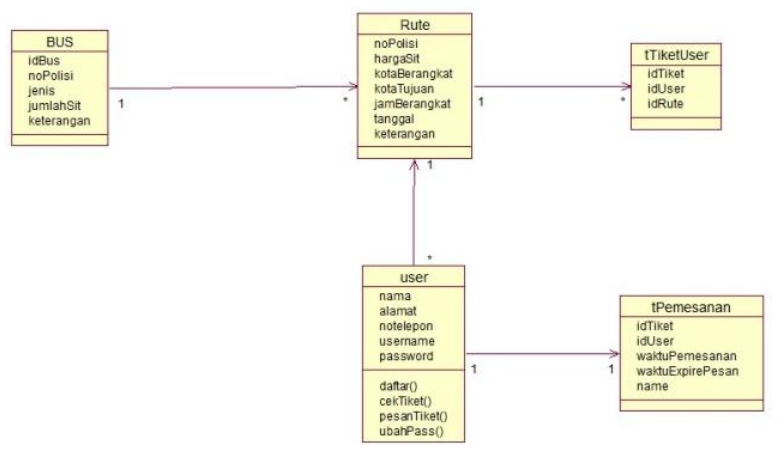

Gambar 10ClassDiagram Sistem

Gambar 9 menggambarkan aktifitas verifikasi pembayaran tiket bus. Pertama yang dilakukan oleh user adalah memilih menu lihat pemasanan. Pada list daftar pemesanan terdapat sub menu verifikasi, setelah user memilih menu verifikasi mana akan munculformverifikasi. Setelah usermengisi form secara otomatis sistem akan mengirimkanrequest ke database dan sistem akan memberikan alert pengir iman verifikasi sukses.

Class Diagram adalah sebuah spesifikasi yang jika diinstansiasi akan menghasilkan sebuah objek dan merupakan inti dari pengembangan dan desain berorientasi objek. Class menggambarkan keadaan (atribut/properti) suatu sistem, sekaligus menawarkan layanan untuk memanipulasi 
keadaan tersebut (metoda/fungsi) [11]. Gambar 10 merupakan diagram class dari sistem aplikasi ini.

Gambar 10 merupakan class diagram dari aplikasi yang dibuat. Terdiri dari beberapa class yaitu Bus, Rute, tTiketUser, user, dan tPemesanan. ClassUser merupakan class utama pada class diagram yang dirancang. Dalam class ini terdapat semua fungsi yang diperlukan untuk menjalankan aplikasi. Class yang lain hanya mengakses fungsi dari class utama tersebut.Sehingga setiap class yang ada pada class diagram tersebut memiliki hubungan dengan classUser.

Deployment diagram adalah susunan fis ik sebuah sistem, menunjukkan tata letak bagianbagian software yang berjalan pada bagian-bagian hardware. Gambar 11 menunjukan Deployment diagram untuk aplikasi yang akan dibuat.

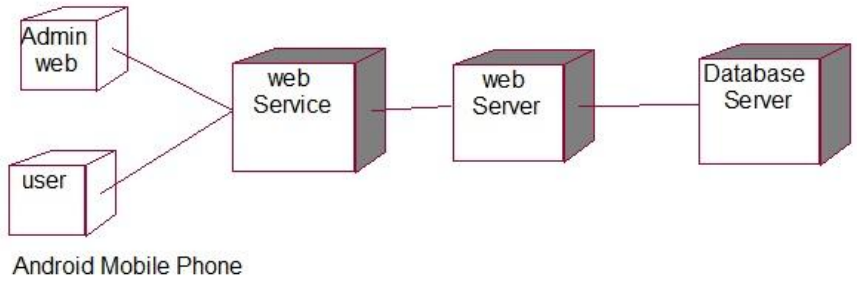

Gambar 11Deployment Diagram

Gambar 11 merupakan deployment diagram dari sistem yang akan dibuat, terlihat bahwa ada beberapa perangkat yang digunakan saat deployment, yaitu sebuah komputer yang bertugas sebagai server yang di dalamnya terdapat database yang digunakan untuk menyimpan data-data admin serta android device untuk client yang bertindak sebagai pengguna aplikasi. Client akan terhubung dengan web server ketika melakukan akses data atau input data seperti melakukan registrasi, dan me lakukan reservasi tiket.

- $\quad$ Evaluasi protoptyping

Setelah aplikasi selesai dibuat, maka pada tahap ini dilakukan testing aplikasi terhadap user. Testing aplikasi ini bertujuan untuk mempermudah melakukan evaluasi terhadap kekurangan yang ada di dalam aplikasi sesuai dengan user requirement pada tahap awal.Ini merupakan tahap paling akhir yang ada di dalam prototyping, apakah tujuan umum dari pembuatan software ini telah tercapai.Apabila belum tercapai maka tahap selanjutnya yang harus dilakukan adalah kembali ke tahap paling awal, begitu seterusnya sampai tujuan umum dapat tercapai.

\section{Hasil Dan Pembahasan}

Hasil dan pembahasan meliputi pembuatan aplikasi mobile untuk reservasi tiket bus. Hasil yang dibahas adalah penerapan web service dengan client berupa aplikasi web dan aplikasi Android mobile yang dapat digunakan sesuai dengan analis is kebutuhan yang telah dilakukan. Terdapat dua aplikasi untuk aplikasi reservasi tiket bus ini, yaitu aplikasi mobile dan aplikasi web. Kedua aplikasi dihubungkan oleh libraryksoap2-android. Kode Program 1 adalah perintah untuk koneksi menggunakan ksoap2-android.

Kode Program 1Perintah Untuk Target Koneksi

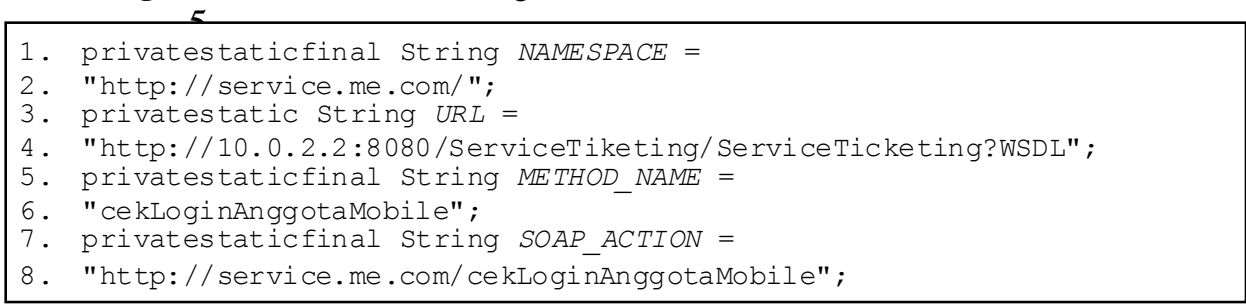

Kode Program1 merupakan perintah untuk menentukan target koneksi dari aplikasi mobile ke aplikasi web. Perintah pemanggilan koneksi dapat dilihat pada Kode Program 2. 
Kode Program 2 Perintah Untuk Pemanggilan Koneksi

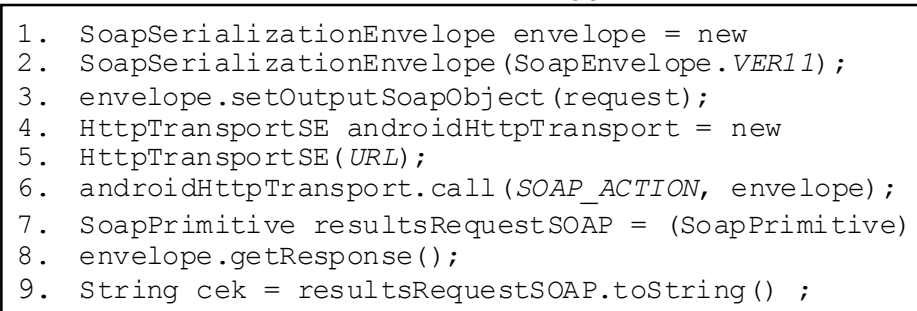

Tampilan awal dari aplikasi client adalah form login, yang mengharuskan user memasukkan username dan password terlebih dahulu untuk dapat menggunakan aplikasi. Namun jika user belum mempunyai username dan password atau belum terdaftar, bisa melakukan registrasi seperti yang tampak pada Gambar 12.

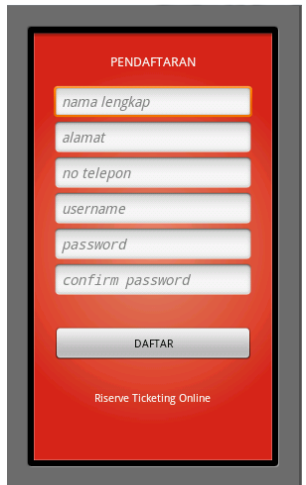

Gambar 12Form Registrasi User

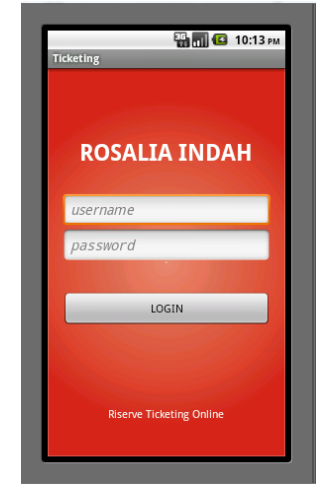

Gambar 13 Halaman Login User

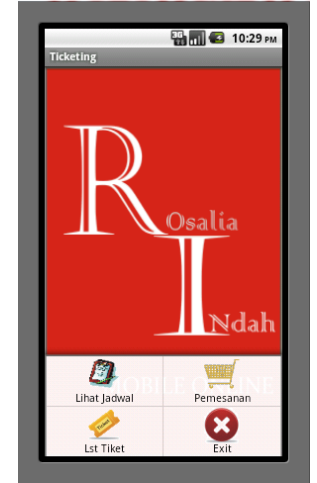

Gambar 14 Halaman Home

Gambar 12 merupakan form registrasi untuk user yang ingin mendaftar menjadi member. Informasi yang di-input-kan kemudian akan tersimpan ke dalam database.Halaman login user ditunjukkan seperti yang tampak pada Gambar 13.

Berdasarkan Gambar 13userdiharuskan mengisikan username dan password.Username dan password diisikan berdasarkan registrasi user yang telah dilakukan sebelumnya. Jika data yang dimasukkan sesuai maka user bisa langsung masuk ke halaman utama. Halaman utama dari userditunjukkan pada Gambar 14.

Gambar 14 merupakan halaman home dari aplikasi reservasi ini. User dapat keluar dari aplikasi dengan menekan tombol Exit. Jika tombol menu yang ada pada device android ditekan akan muncul lima menu yaitu lihat jadwal, pemesanan,List tiket, account dan exit. Tiga menu paling penting yang akan dibahas selanjutnya yaitu menu lihat jadwal, pemesanan,dan list tiket, karena menu ini berfungsi dalam pemesanan tiket.

Menu lihat jadwal jika dipilih maka tampilannya seperti Gambar 15.

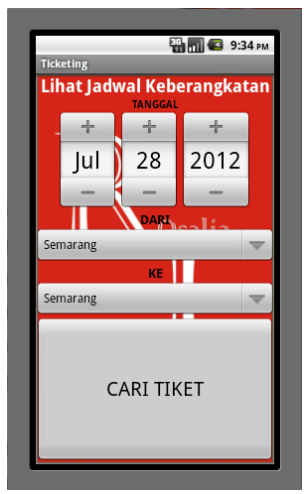

Gambar 15 Menu Lihat Jad wal

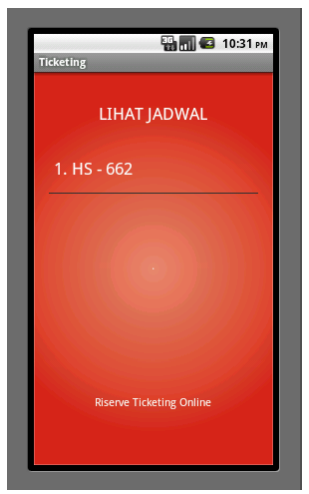

Gambar 16 Hala man Data Jadwal

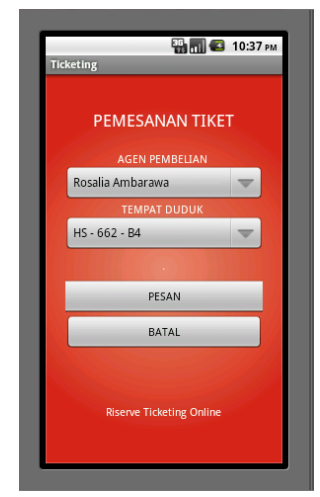

Gambar 17 Halaman Pemesanan Tiket 
Pada Gambar 15 tersebut memperlihatkan halaman lihat jadwal buspada aplikasi.User harus mengisi form pencarian jadwal keberangkatan bus sesuai dengan tanggal, asal, dan tujuan keberangkatan.Jika tombol cari telah diklik maka akan keluar data jadwal keberangkatan bus yang dipilih seperti pada Gambar 16.

Gambar 16 merupakan tampilan ketika user memencet tombol cari. Seperti contoh sebelumnya jikauser memilih jadwal berangkatan pada tanggal 30 juli 2012 dari Semarang ke Solo, setelah tombol cari diklikmaka keluar data jadwal keberangkatan dari pencarian tersebut. User dapat memesan tiket dengan mengklik pesan pada salah satu jadwal keberangkatan. Saat user klik salah satu data jadwal keberangkatan,user klik pesan maka user akan masuk ke menu pemesanan tiket seperti terlihat pada Gambar 17.

Gambar 17 merupakan halaman pemesanan tiket di mana user akan memilih agen keberangkatan dan tempat duduk yang di inginkan.User dapat memilih menu verifikasi untuk melakukan verifikasi pembayaran tiket seperti terlihat pada Gambar 18.

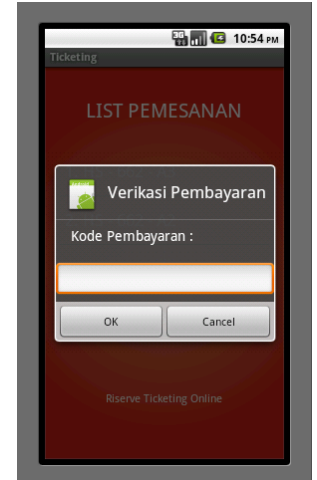

Gambar 18 Halaman Verifikasi Pembayaran

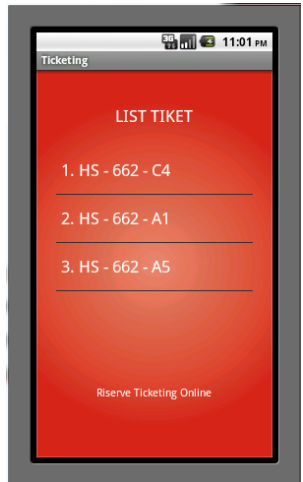

Gambar 19 Halaman List Tiket

Pada Gambar 18 merupakan tampilan halaman konfirmasi pembayaran. Pada halaman ini user harus mengisi form konf irmasi dengan mencantumkan kode transaksi pembayaran via bank. Setelah melakukan proses konfirmasi maka userakan dinyatakan fix memesan tiket. Daftar tiket yang sudah fix dapat dilihat pada menu list tiket seperti Gambar 19.

Gambar 19 merupakan tampilan dari halaman list tiket. Pada menu ini menampilkan daftar tiket yang sudah dipesan oleh user dan sudah melakukan verif ikasi pembayaran.

\section{Antarmuka Aplikasi Web Admin}

Tampilan awal dari aplikasi web admin adalah form login, yang mengharuskan admin memasukkan username dan password terlebih dahulu untuk dapat mengakses seluruh halaman web. Gambar 20 menunjukkan halaman login untuk admin.
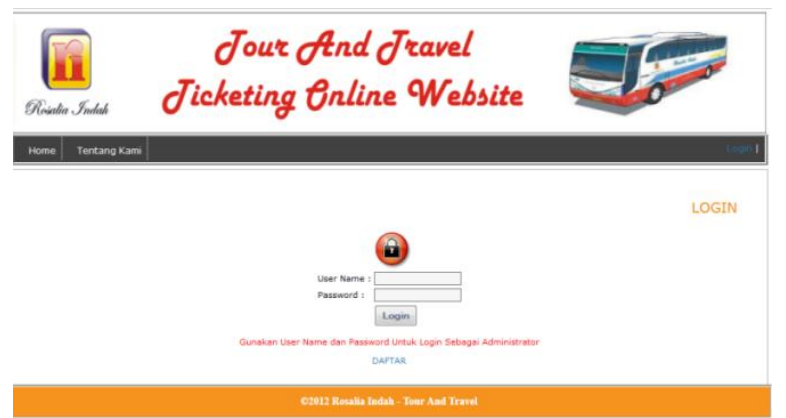

Gambar 20 Halaman Login Admin

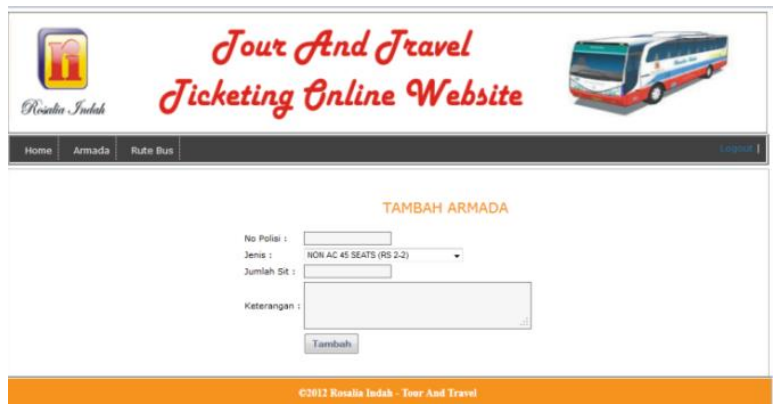

Gambar 21 Halaman Add Armada 
Gambar 20 merupakan tampilan halaman login untuk admin.Jika data yang dimasukkan sesuai maka admin bisa langsung masuk ke halaman utama. Admin yang telah berhasil login kemudian masuk ke halaman home. Admin bisa me-manage semua data tentang aplikasi reservasi tiket bus P.O Rosalia Indah dengan menu armada dan rute bus. Pada menuarmada terdapat 2 kategori data yang bisa diolah, yaitu data $a d d$ armada, dan kelola armada. Pada menu rute bus, admin dapat menambah rute bus dan kelola pemesanan tiket.Pada data pemesanan tiket admin dapat melihat daftar user yang memesan tiket dan daftar penumpang tiap armadanya. Jika admin memilih menu add armada maka tampilannya akan seperti Gambar 21.

Gambar 21 merupakan halaman tambah data armada yang tersedia. Data yang dibutuhkan untuk menambah data armada adalah nama no polisi, jenis armada, jumlah sit, dan keterangan.Admin juga dapat mengelola data rute tiap armada yang tersedia. Gambar 22 menunjukan tampilan untuk tambah data rute.

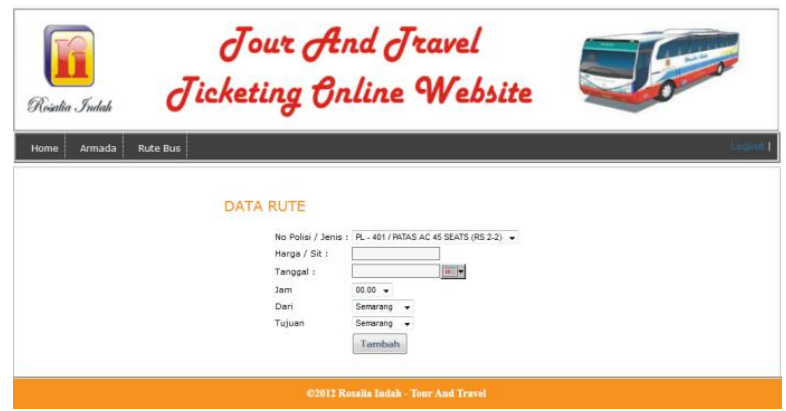

Gambar 22Tambah Data Rute

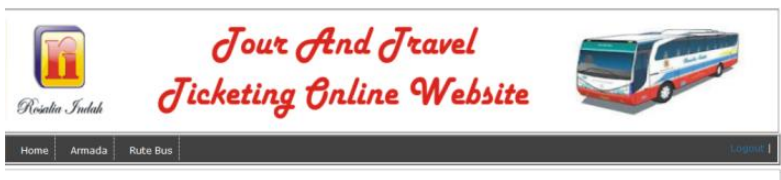

DATA RUTE BUS

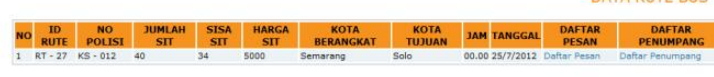

Gambar 23 Halaman Kelola Rute Bus

Gambar 22 merupakan halaman tambah data rute armada yang tersedia.Data yang dibutuhkan untuk menambah data rute armada adalah no polisi atau jenis armada, harga/sit, tanggat, jam, asal keberangkatan dan tujuan. Kemudian untuk menge lola data pemesan dan daftar penumpang, admin dapat memilih menu kelola rute bus seperti Gambar 23.

Gambar 23 merupakan halaman ke lola data rute bus. Data yang ditampilkan pada menu ini adalah id_rute, no polisi, jumlah sit, sisa sit, harga/sit,kota berangkat, kota tujuan, tanggat, jam, daftar pemesan, daftar penumpang. Gambar 24menunjukan halaman daftar pesan.

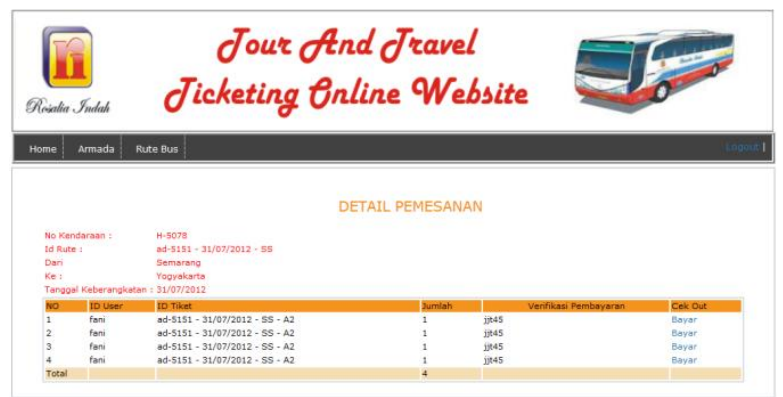

Gambar 24 Halaman Daftar Pesan

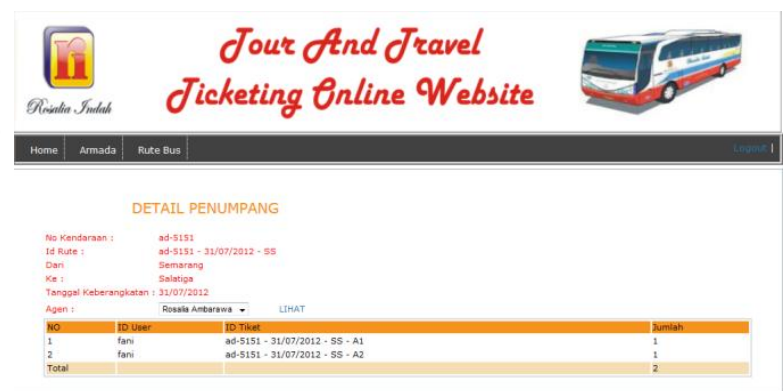

Gambar 25 Halaman Daftar Penu mpang

Gambar 24menunjukan daftar pesan yang merupakan data dari calon penumpang, untuk calon penumpang yang belum melakukan konfirmasi pembayaran tiket maka nilai varifikasi pembayaran adalah 0 . Setelah user melakukan verifikasi pembayaran, admin dapat memilih cek out bayar maka data akan langsung masuk ke daftar penumpang seperti Gambar 25.

Gambar 25 merupakan halaman daftar penumpang. Pada halaman ini adalah data dari penumpang yang sudah melakukan konfirmasi pembayaran dan dinyatakan fix memesan tiket. 


\section{Pengujian Sistem}

Tahap pengujian sistem ini merupakan tahapan saat seorang pengembang aplikasi melakukan pengujian terhadap sistem yang sudah dirancang. Tahap ini merupakan tahapan untuk menemukan beberapa kekurangan yang ada dalam sistem. Pengujian aplikasi ini seperti yang dijelaskan pada tahap sebelumnya, menggunakan dua teknik pengujian, yaitu:

\section{Pengujian Alfa}

Pengujian alfa merupakan pengujian program yang dilakukan oleh pembuat aplikasi ataupun orang-orang yang terlibat di dalamnya. Pengujian alfa hanya untuk sirkulasi internal dan masalah (error) atau ketidaklengkapan yang terdapat dalam aplikasi dapat diduga sebelumnya [12]. Pada tahap ini pengujian dilakukan dengan metode blackbox. Untuk rincian pengujian dapat dilihat pada Table 1 berikut :

a. Pengujian Login yaitu untuk mengecek apakah fungsional dari formlogin telah berjalan dengan baik. Dari pengujian yang dilakukan didapatkan kesimpulan bahwa form login telah berfungsi dengan baik.

Tabel 1 Pengujian Black Box untuk form login

\begin{tabular}{|c|c|c|c|}
\hline $\begin{array}{c}\text { Aktivitas } \\
\text { dan } \\
\text { Event }\end{array}$ & Input & Output & $\begin{array}{c}\text { Status } \\
\text { Pengujian }\end{array}$ \\
\hline $\begin{array}{l}\text { Loginuser dengan klik } \\
\text { tombol login }\end{array}$ & $\begin{array}{l}\text { Username dan } \\
\text { password }\end{array}$ & $\begin{array}{l}\text { a. Jika berhasil maka masuk halaman } \\
\text { home } \\
\text { b. Jika password salah maka muncul } \\
\text { peringangatan password salah } \\
\text { c. Jika username salah muncul peringatan } \\
\text { user belum tersedia }\end{array}$ & Valid \\
\hline $\begin{array}{l}\text { Login admin dengan klik } \\
\text { tombol login }\end{array}$ & $\begin{array}{l}\text { Username dan } \\
\text { password }\end{array}$ & $\begin{array}{l}\text { a. Jika berhasil maka masuk halaman } \\
\text { admin } \\
\text { b. Jika password salah maka muncul } \\
\text { peringangatan password salah } \\
\text { c. Jika username salah muncul peringatan } \\
\text { user belum tersedia }\end{array}$ & Valid \\
\hline
\end{tabular}

b. Pengujian untuk menu-menu yang dapat diakses user pada aplikasi mobile meliputi menu lihat jadwal, pemesanan, list pemesanan, dan verifikasi pembayaran. Dari pengujian yang dilakukan didapatkan kesimpulan bahwa semua menu telah berfungsi dengan baik.

Tabel 2Pengujian Black Box untuk menu yang dapat diakses user

\begin{tabular}{|c|c|c|c|}
\hline $\begin{array}{l}\text { Aktivitas } \\
\text { dan } \\
\text { Event }\end{array}$ & Input & Output & $\begin{array}{c}\text { Status } \\
\text { Pengujian }\end{array}$ \\
\hline $\begin{array}{l}\text { Lihat jadwal } \\
\text { keberangkatan }\end{array}$ & $\begin{array}{l}\text { Memilih tanggal, asal, } \\
\text { dan tujuan keberangkatan }\end{array}$ & $\begin{array}{l}\text { a. Jika jadwal ditemukan maka akan } \\
\text { muncul menu lihat data } \\
\text { b. Jika jadwal tidak ditemukan muncul } \\
\text { komentar "tidak ada jadwal } \\
\text { keberangkatan" }\end{array}$ & valid \\
\hline User memesan tiket & $\begin{array}{l}\text { Memilih } \\
\text { keberangkatan } \\
\text { tempat duduk. }\end{array}$ & $\begin{array}{l}\text { a. Jika pilih pesan maka masuk ke list } \\
\text { pemesanan } \\
\text { b. Jika batal maka kembali ke menu } \\
\text { lihat data }\end{array}$ & valid \\
\hline $\begin{array}{l}\text { Melakukan } \\
\text { verifikasi } \\
\text { pembayaran }\end{array}$ & $\begin{array}{l}\text { Memasukkan kode } \\
\text { transfer pembayaran }\end{array}$ & $\begin{array}{l}\text { a. Jika tidak me masukkan kode transfer } \\
\text { maka akan muncul peringatan : *kode } \\
\text { belum di isi } \\
\text { b. Jika telah me masukkan kode transfer } \\
\text { maka masuk ke menu list tiket }\end{array}$ & valid \\
\hline Melihat list tiket & & Menampilkan daftar tiket yang dipesan & valid \\
\hline
\end{tabular}


c. Pengujian untuk menu-menu yang dapat diakses admin didapatkan kesimpulan bahwa telah berfungsi dengan baik

Tabel3Pengujian Black Box untuk menu yang dapat diakses admin

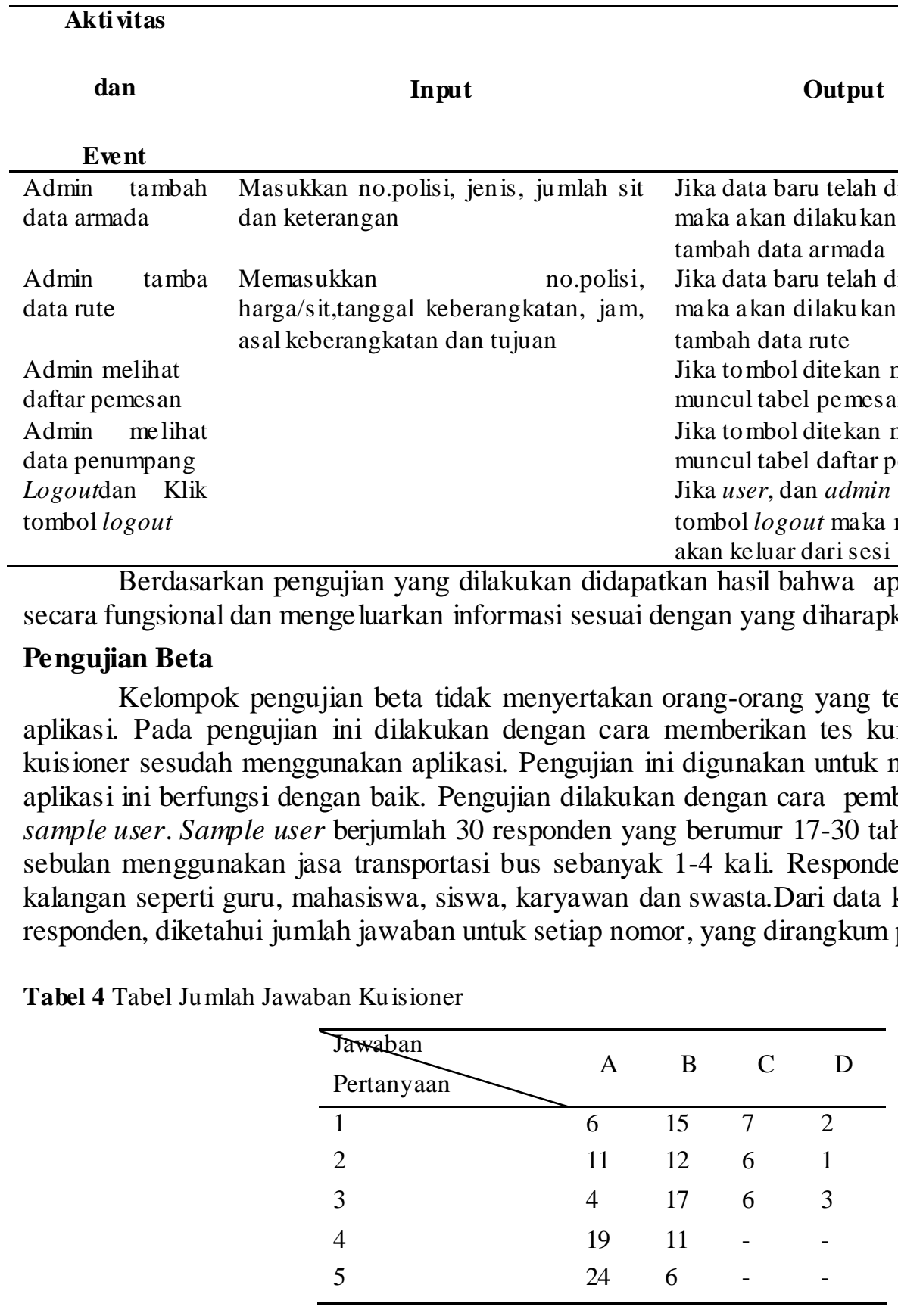

Tahap selanjutnya adalah menguji tanggapan dari para responden yang sudah mengisi kuesioner, dihitung dengan menggunakan skala Likert untuk menghitung skala pengukuran variabel, masing-masing kategori jawaban diberi skala skor 1-4.

$\begin{array}{lll}\text { 1. } & \text { Sangat Baik }(\mathrm{SB}) & =4 \\ \text { 2. } & \text { Baik }(\mathrm{B}) & =3 \\ \text { 3. } & \text { Cukup }(\mathrm{C}) & =2 \\ \text { 4. } & \text { Tidak Baik } & =1\end{array}$


Berdasarkan hasil analisa jawaban kuesioner yang telah dilakukan, pada pertanyaan pertama $20 \%$ responden menjawab sangat mudah digunakan dan 50\% menjawab mudah digunakan, sehingga untuk pertanyaan pertama dapat disimpulkan bahwa $70 \%$ responden menyatakan aplikasi ini mudah digunakan.

Berdasarkan hasil analisa jawaban kuesioner yang telah dilakukan pada pertanyaan kedua $36,67 \%$ responden menjawab sangat membantu dan $40 \%$ menjawab membantu, sehingga untuk pertanyaan kedua dapat disimpulkan bahwa $76,67 \%$ responden menyatakan aplikasi ini dapat membantu dan mempermudah customer dalam memesan tiket bus.

Berdasarkan hasil analisa jawaban kuesioner pertanyaan ketiga 13,33\% responden menjawab sangat mudah dipahami dan 56,67\% menjawab mudah dipahami, sehingga untuk pertanyaan ketiga dapat disimpulkan bahwa $70 \%$ responden menyatakan cara pemesanan tiket pada aplikasi ini mudah dipahami.

Berdasarkan hasil analisa jawaban kuesioner pertanyaan ke-empat 63,33\% responden menjawab fleksibel, sehingga untuk pertanyaan keempat dapat disimpulkan bahwa 63,33\% customer menyatakan aplikasi reservasi ini lebih fleksibel dari sistem sebelumnya.

Berdasarkan hasil analisa jawaban kuesioner yang te lah dilakukan pada pertanyaan terakhir $80 \%$ responden menjawab setuju, sehingga untuk pertanyaan kelima dapat disimpulkan bahwa $80 \%$ customer menyatakan setuju untuk mengganti sistem reservasi yang lama dengan aplikasi reservasi mobile ini.

\section{Kesimpulan}

Dari hasil penelitian dan pengujian yang telah dilakukan, dapat diambil simpulan bahwa aplikasi reservasi tiket bus berbasis Android dapat diterapkan pada PO.Rosalia Indah untuk penjualan tiket seluruh trayek. Aplikasi mobile dengan tampilan yang sederhana dan user input yang tidak rumit dapat digunakan dalam melakukan reservasi tiket secara online. Aplikasi ini dapat membantu user menghemat waktu, biaya, dan tenaga dalam pembelian suatu produk, karena menggunakan mobile device yang bersifat ubiquity sehingga transaksi bisa dilakukan kapan saja dan dimana saja.

\section{Daftar Pus taka/Pustaka Acuan}

[1] Rosalia Indah. 2012. Company Profile. Surakarta.

[2] Microsoft Corp. (2000) Application Service Provider: Evolution and Resources,White Paper, USA.

[3] Janwar. 2010. Perancangan aplikasi Pemesanan Tiket dan Penjadwalan Keberangkatan Bus Antar Propinsi Berbasis web (Studi kasus: PO. Maju Lancar.)Jakarta: Universitas Mercu Buana

[4] Faizal. 2011. Aplikasi Layanan Pesan Makanan Pada Restoran “XYZ” Dengan platform Android. Bandung : Politeknik Telkom.

[5] Nazruddin Safaat H. 2011. Pemograman Aplikasi Mobile Smartphone dan Tablet PC Berbasis Android. Bandung : Informatika

[6] Android Developer. 2011. What is Android ?. Diakses tanggal 25 November 2011.

[7] Kreger, H., 2001, Web-services Conceptual Architecture (WSCA 1.0), IBM Software Group, USA

[8] Lily, dkk. 2006. Toward Web Service. Proceeding, Seminar Ilmiah Nasional Komputer dan Sistem Intelijen (KOMMIT 2006).

[9] Pressman, Roger, 2002, Rekayasa Perangkat Lunak: Pendekatan Praktisi (Buku Satu), Yogyakarta: Penerbit ANDI dan McGraw-Hill Book Co

[10] Nugroho, Adi. 2005. Rational Rose Untuk Pemodelan Berorientasi Objek. Bandung: Informatika.

[11] UML 1.3a lphaR S, Object ManagemenGt roup Inc, March 1999.

[12] Vaughan, Tay. 2004. Multimedia: Making It Work, Edisi 6. Yogyakarta: ANDI. 